\title{
When science and politics come together: From depletion to recovery of the stratospheric ozone hole
}

\author{
This article belongs to Ambio's 50th Anniversary Collection. Theme: Ozone Layer
}

\author{
Claudia Mohr
}

Published online: 21 November 2020

"The world solved the ozone problem. It can solve climate
change". Such was the headline of an opinion piece in The
New York Times in $2019,{ }^{1}$ when topics other than the
COVID-19 pandemic still made headlines. It referred to the
fact that the layer of ozone molecules present in the
atmosphere was slowly recovering from destruction due to
human activities. It was, however, also human action that
had enabled the recovery of the ozone layer, and this
sparked the outburst of optimism by The New York Times.
Ambio had its role in this success story, as it was one of the
journals where the scientific discoveries that laid the
foundation for political action were discussed.

Ozone $\left(\mathrm{O}_{3}\right)$ is a natural constituent of the Earth's atmosphere. It absorbs radiation in the ultraviolet (UV) and infrared (IR) ranges of the electromagnetic spectrum and plays therefore an important role in the regulation of the atmosphere's radiation and temperature budget. High concentrations of ozone, the so-called ozone layer, are found in the stratosphere, at altitudes of 10 to $50 \mathrm{~km}$ in the atmosphere. The ozone layer shields humans, animals, and plants from biologically damaging UV radiation-without the absorptive properties of this molecule, life on Earth would not be possible. Ozone is formed from and reconverted to molecular oxygen via reactions that involve photodissociation. However, the levels of ozone found in the stratosphere can only be explained if additional loss mechanisms are taken into account. These are reaction cycles that involve catalysts such as hydrogen, hydroxyl, and halogen radicals such as bromine and chlorine, and nitrogen oxides (Crutzen 1974).

This understanding was developed gradually in the second half of the last century. The work of chemists Paul Crutzen, Mario Molina, Sherwood Rowland, and colleagues in the 1970s led to the insight that the ozone layer in the stratosphere was being depleted and that the substances responsible for the depletion were emitted by human activities: nitrogen oxides from the use of nitrates as fertilizers, and halogen radicals from chlorofluorocarbons (CFCs) and related compounds, used as propellant gas in aerosol spray cans, and refrigerants in refrigerators and airconditioners (Molina and Rowland 1974). Crutzen, Molina, and Rowland were awarded the Nobel Prize in Chemistry in 1995 for their work in atmospheric chemistry and specifically ozone formation and decomposition.

Their work eventually led to one of the likely most successful agreements in the history of international environmental politics: The Montreal Protocol. Entered into force in 1989, this international treaty was designed to protect the ozone layer by phasing out the production of ozone-depleting substances, such as CFCs. Political pressure had grown after the detection of the ozone hole over Antarctica in the 1980s (Farman et al. 1985), caused by chlorine atoms produced photochemically in significant amounts in the stratosphere from CFCs that are inert at lower altitudes. The Montreal Protocol indeed led to a halt of the production of ozone-depleting substances, and the recovery of the ozone layer can be observed today. It is a great example for the good that can come out when science, the public, and policy-makers come together.

The scientific discussions that were of eminent importance at the time also happened in part through Ambio: In 1974, Paul Crutzen wrote an article about the possible variations in total ozone due to natural processes and human activities such as superconic aircraft, CFC production, nuclear warfare, and the use of nitrogen fertilizers (Crutzen 1974). Another article, written in 1977 together with Dieter H. Ehhalt, focuses in more detail on the effect

\footnotetext{
${ }^{1}$ December 17, 2019. www.nytimes.com/2019/12/07/opinion/ sunday/ozone-climate-change.html.
} 
of nitrous oxide $\left(\mathrm{N}_{2} \mathrm{O}\right)$ emissions on ozone destruction (Crutzen and Ehhalt 1977). Nitrous oxide emitted from the application of fertilizer, among other processes, breaks down in the stratosphere and represents a source of ozonedepleting nitrogen oxides.

For this Ambio anniversary collection, Dr. Rolf Müller, a colleague of Dieter H. Ehhalt at Forschungszentrum Juelich, describes in his article in more detail the scientific significance of this paper (Müller 2021). Merete Bilde, Professor at Aarhus University and Ambio advisory board member, together with Ole John Nielsen, Professor at University of Copenhagen, and Susan Solomon, Professor at the Massachusetts Institute of Technology in Cambridge, were asked to provide a reflection on the Ambio articles of Paul Crutzen and Dieter H. Ehhalt from the 1970s. Both Bilde and Nielsen, as well as Solomon, herself a renowned scientist pivotal in the understanding of the Antarctic Ozone hole, provide in their reflections a summary of Crutzen and Ehhalts' articles, and their own view on their significance and legacy for today and the future. Bilde and Nielsen (2021) write that "these two articles represent the beginning of a scientific era, which led to the discovery of the Antarctic ozone hole and political action in the form of the Montreal protocol and its amendments", and according to Solomon (2021), the articles "remain guideposts today for ongoing international negotiations regarding reducing emissions from fertilizer and limiting nuclear testing". It is not often in climate sciences that one gets to write about the work of a Nobel laureate and scientist of the format of Paul Crutzen. He is a central figure in the fight for the acceptance of global climate change and has coined the term "Anthropocene". It is with pride that we can say that Ambio was part of the scientific debate that led to unraveling of the mechanisms of the depletion of the ozone layer. The topic fit well in Ambio at the time and does so now, with its clear link between human activities and their effects on the environment. Paul Crutzen explicitly included policy recommendations in his articles. Here's to hope that the story of the recovery of the ozone hole will serve as an example for one of the biggest challenges we face today-climate change.

\section{REFERENCES}

Bilde, M., and Nielsen, O. J. 2021. Reflection on two Ambio papers by P. J. Crutzen on ozone in the upper atmosphere. 50th Anniversary Collection: Ozone layer. Ambio Volume 50.

Crutzen, P.J. 1974. Estimates of possible variations in total ozone due to natural causes and human activities. Ambio 3: 201-210.

Crutzen, P.J., and D.H. Ehhalt. 1977. Effects of nitrogen fertilizers and combustion on the stratospheric ozone layer. Ambio 6: 112-117.

Farman, J.C., B.G. Gardiner, and J.D. Shanklin. 1985. Large losses of total ozone in Antarctica reveal seasonal $\mathrm{ClOx} / \mathrm{NOx}$ interaction. Nature 315: 207-210.

Molina, M.J., and F.S. Rowland. 1974. Stratospheric sink for chlorofluoromethanes: chlorine atmo-catalyzed destruction of ozone. Nature 249: 810-812.

Müller, R. 2021. The impact of the rise in atmospheric nitrous oxide on stratospheric ozone. 50th Anniversary Collection: Ozone layer. Ambio Volume 50.

Solomon, S. 2021. Risks to the stratospheric ozone shield in the Anthropocene. 50th Anniversary Collection: Ozone layer. Ambio Volume 50.

Publisher's Note Springer Nature remains neutral with regard to jurisdictional claims in published maps and institutional affiliations.

\section{AUTHOR BIOGRAPHY}

\section{Claudia Mohr $(\square)$}

Address: Department of Environmental Science, Stockholm University, 10691 Stockholm, Sweden.

e-mail: claudia.mohr@aces.su.se 


\title{
Estimates of Possible Variations in Total Ozone Due to Natural Causes and Human Activities
}

\author{
BY PAUL J CRUTZEN
}

\section{The ozone layer in the atmosphere protects life on Earth from a deadly overdose of ultraviolet radiation from the sun. The author has calculated that the following would reduce the mean global amount of ozone: - a doubling of the 1972 production of freons, at present mainly used in aerosol cans, refrigeration and in foam plastic: a 12 percent reduction - a nuclear attack wiping out one world power: a fifty percent reduction - a fleet of 500 SSTs flying at $21 \mathrm{~km}$ for 11 hours per day: a 12 percent reduction globally, 20 percent locally - a 20 percent increase in the global production of nitrous oxides: a four percent reduction.}

Ozone (see chemical nomenclature on page 209) is an extremely important minor constituent of the earth's atmosphere, despite the fact that its total global mean abundance is not more than the number of molecules in a 3.5 $\mathrm{mm}$ thick layer of air at sea level. This small amount of ozone is essential for the protection of life on earth from lethal ultraviolet radiation of wavelengths shorter than 300 $\mathrm{nm}(1 \mathrm{~nm}=1$ nanometer $=1$ thousand-millionth of a meter). Molecules of DNA, containing the genetic information, exhibit the most marked absorption of ultraviolet radiation in the wavelength region around $265 \mathrm{~nm}$, while the absorption of proteins is highest from 275 to $285 \mathrm{~nm}$. However, a weak absorption of ultraviolet radiation by these vital compounds takes place also near and above $300 \mathrm{~nm}$ and the shielding from ultraviolet radiation by ozone is, therefore, not perfect under present conditions as some solar radiation penetrates down to ground level near $300 \mathrm{~nm}$. If the protecting cover of ozone in the atmosphere were to decrease to half its present amount, the cut-off wavelength of ultraviolet radiation would be reduced from $298 \mathrm{~nm}$ towards $290 \mathrm{~nm}$, which is closer to the wavelength region of maximum absorption by DNA and proteins. It is known that there are a number of negative effects of solar ultraviolet radiation on living matter even under present conditions. Present knowledge of the effects of increased ultraviolet radiation at ground levels has been summarized in a report by an expert committee of the US Academy of Sciences (1). To mention a few effects: skin cancers are caused by exposure to intense ultraviolet radiation; photosynthesis of plants is inhibited and their growth is reduced and some plants can even die due to the action of ultraviolet radiation; the most abundant animal species, the insects, can see in the ultraviolet region of the spectrum, which penetrates to ground level, and they rely for their navigation and behavior on the polarization of the sky radiation in this wavelength region. All higher forms of life have developed defense and repair mechanisms against ultraviolet radiation damage; their survival depends partly on their ability to keep up with the ultraviolet radiation stress. There is little doubt that a reduction in total ozone to 50 percent of its present abundance would have far-reaching effects for ecological and biological systems on earth, which suggests that for many millions of years the total amount of ozone in the atmosphere can not have been much less than at present. Although it may not seem likely that depletions of ozone by as much as 50 percent are going to take place, there has been growing concern about the biological effects of increased ultraviolet radiation intensities at ground level. It has been indicated during recent years that important reductions in atmospheric ozone may be caused by a number of human activities, such as stratospheric aviation, increased use of nitrates as fertilizers and the use of chlorofluoromethanes (mostly known under the name "freons", see chemical nomenclature). With the present article we follow up a paper in this journal two years ago (2) which presented a review of knowledge and hypotheses of stratospheric chemistry at that time and which also discussed the possibility of pollution of the stratosphere by exhaust gases of supersonic aircraft.

\section{SOME PHYSICAL AND CHEMICAL FACTS ABOUT} THE STRATOSPHERE

Ozone is located mainly in the stratosphere, which is the region of the atmosphere in the altitude range from 10 to $50 \mathrm{~km}$ at high latitudes and 18 to $50 \mathrm{~km}$ at low latitudes. The mass of the stratosphere is about 20 percent of the total atmospheric mass. The dominant energy source for the stratosphere is the absorption of ultraviolet radiation by ozone and it is this absorption process which explains 


\title{
Effects of Nitrogen Fertilizers and Combustion on the Stratospheric Ozone Layer
}

\author{
BY PAUL J CRUTZEN AND DIETER H EHHALT
}

Increased use of fixed nitrogen as fertilizer might result in a reduction of the earth's ozone shield of a few percent at the beginning of the 21 st century and 10 percent by the end of that century. Emissions of $\mathrm{N}_{2} \mathrm{O}$ from coal combustion might also contribute significantly to the problem.

The future "health" of the earth's ozone layer under the influence of man's expanding industrial and agricultural activities has become a political. (iculical economic and scientific issue which has aroused worldwide interest. One of the most remarkable features about atmospheric ozone is that its total abundance in the atmosphere is almost sufficient to prevent the penetration of biologically damaging ultraviolet radiation to ground level. Nevertheless, some of this radiation reaches the ground. Since its penetration is particularly depend its penetration is particularly dependen on the amount of overhead ozone, it is important to know the biological consequences of depletions of the atmospheric ozone content.

An important piece of information as to possible detrimental biological effects of decreasing ozone amounts is provided by the correlation between skin cancer inc dence (especially non-melanoma cases) and solar ultraviolet radiation exposure Although it would be remarkable if this were shown to be the only negative side effect of reductions in the ozone shield, it is difficult to quantify other effects. Increased ultraviolet radiation near $300 \mathrm{~nm}$ can reduce overall growth and photosynthesis rates in plants and this may imply reductions in the yields of certain agricultural crops (1-4). Solar ultraviolet radiation is able to penetrate to considerable depths (ten meters) in clear water. and phytoplankton (the microscopic green plants which are the base of the aquatic food chain) are sensitive to ultraviote radiation (4). On the other hand the exist-

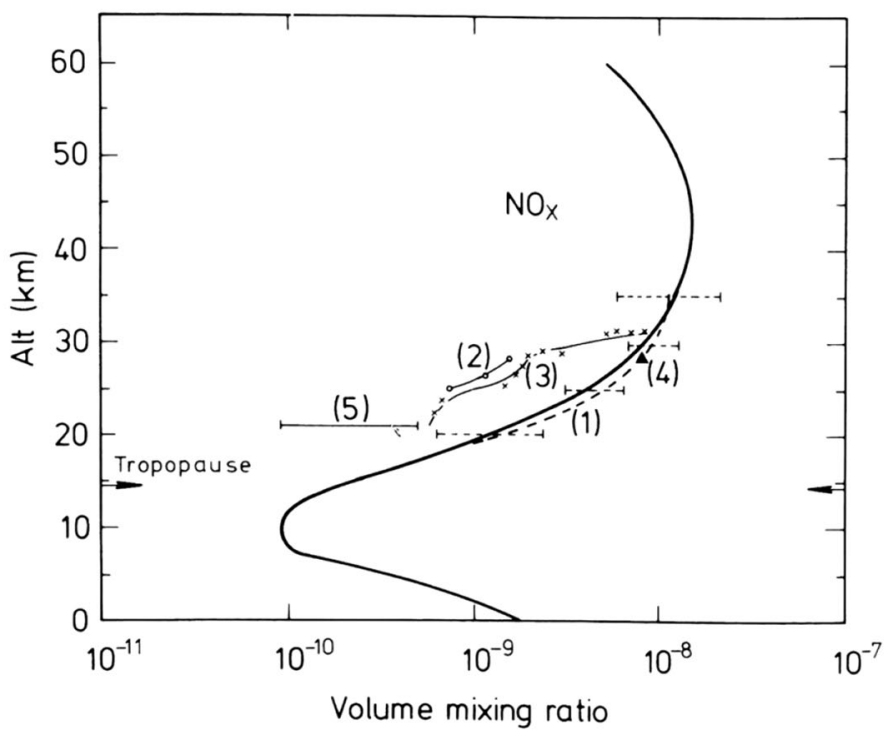

Figure 1. $\mathrm{NO}_{x}\left(\mathrm{NO}+\mathrm{NO}_{2}\right.$ ) volume mixing ratios. The full line shows model calculations of yearly averages. The numbered curves

(1) Ackerman et al (58), $44 \mathrm{~N}$

(2) Ridley et al (59), $30 \mathrm{~N}$.

(3) Ridley et al (60), $30 \mathrm{~N}$.

(5) Latel et al (61), $33^{\circ} \mathrm{N}$. 